\title{
A Study on International Publicity Translation in the English Translation of Fighting COVID-19: China in Action from the Perspective of Manipulation Theory
}

\author{
Chunying Guo
}

\author{
School of Translation and Interpreting, Beijing Language and Culture University, Beijing, 100089, China \\ E-mail:1016709928@qq.com
}

\begin{abstract} English version of Fighting COVID-19: China in Action. COVID-19: China in Action

\section{INTRODUCTION}

At the end of 2019 COVID-19 broke out and many countries reported confirmed cases soon. Within three months, China has successfully controlled the spreading of the pandemic and offered its valuable experience for the whole world to draw on. On June $7^{\text {th }} 2020$, the State Council released the white paper, Fighting COVID-19: China in Action, to record China's great efforts and achievements in fighting against the pandemic. This paper is based on the manipulation theory of Lefevere and takes the white paper as an example to see how international publicity translation is influenced by ideology, patronage and poetics.
\end{abstract}

International publicity translation serves as a major way for the world to know about China. The effect of communication will hinge on the quality of translation. As such, translators should not be limited within textual equivalence, but take into consideration the different culture and ideology conveyed by the two languages, and render the message in a clear and correct way. Based on the manipulation theory of André Lefevere, this paper focuses on the influence of ideology, patronage, and poetics through the analysis of the

Keywords: international publicity translation, manipulation theory, patronage, ideology, poetics, Fighting

\section{CURRENT STUDIES ON MANIPULATION THEORY AND ITS INFLUENCE IN INTERNATIONAL PUBLICITY TRANSLATION}

In 1985 Theo Hermans ${ }^{[1]}$ put forth the concept of "manipulation" and The Manipulation of Literature was regarded as a representative work in manipulation school of translation studies. Susan Bassnett and Andre Lefevere $(1990)^{[2]}$ put forward the cultural turn of translation studies and Lefevere $(1992)^{[3]}$ mentioned the three factors influencing publicity translation in Translation, Rewriting, and the Manipulation of Literary Fame, namely poetics, ideology and patronage. As such, translation theorists and scholars began to move beyond textual equivalence and focus more on culture dimension.

In recent decades, scholars have expanded the scope of manipulation theory beyond literary translation to include publicity translation. Hu Xingwen and Zhang Jian (2013) $)^{[4]}$ point out that publicity translation refers to the translation of publicity materials. Zeng Jianping and Chen Lin $(2018)^{[5]}$ write in their paper that publicity translation carries the features of both "translation" and "publicity", which makes it different from other types of translation. Translators will rewrite the source text inevitably for desirable acceptance on the part of recipients.

Scholars put considerable store by ideology in analyzing publicity translation. Hu Weiping (2007) ${ }^{[6]}$ analyzes how ideology works from three perspective, namely the amount of translation, translation strategies as well as the materials for translation. Taking the translation of political materials as the example, Hu Fangyi and Jia Wenbo $(2010)^{[7]}$ point out that translators should attach great significance to the ideology of the recipients, so as to achieve ideal effects of translation. Hu Xingwen and Wu Amiao (2013) ${ }^{[8]}$ take the collectivism in Chinese ideology as the example. On account of the fact that Chinese people embrace collectivism while westerners uphold individualism, two scholars believe that proper adjustments, addition and deletion of the source text will contribute to the recipients' better understanding. Some scholars also focus on a specific publicity text to analyze the role of ideology, such as Wang Haiyun and Li Huihui (2016) ${ }^{[9]}$, and Lin Xiaxuan $(2018)^{[10]}$.

Publicity translation is different from other types of translation in that it is a kind of translation carrying the purpose of publicity. As such, the influence of ideology in such translation becomes the predominant focus of studies. Meanwhile poetics and patronage cannot be neglected. The three factors constitute a unity which cannot be separated simply. Therefore, based on the findings of other scholars, this paper is to analyze the influence of poetics, ideology and patronage in the text of Fighting COVID-19: China in Action. 


\section{IDEOLOGY}

The manipulation school of translation indicates that translation is subject to social and cultural restrictions. Publicity translation is considerably influenced by ideology. In this part, an analysis is to be conducted to see the role of ideology, taking the white paper as the example.

\subsection{The Concept of “命运”}

In the white paper, the concept of “人类命运共同体” has been reiterated. President Xi Jinping put forth the idea of “人类命运共同体” at the $18^{\text {th }}$ CPC National Congress in 2012, calling for the international community to pursue win-win cooperation and pay joint effort in coping with issues facing mankind. The government work report is an important channel for the rest of the world to know about China, and its English version is authoritative in the choice of diction and the usage of expressions. By searching in the government work reports from the year 2012 to 2020, it is found out that the expression “命运共同体” has been rendered in the following ways (there is no such a term in the reports of 2012, 2013, 2014):

Table 1 Translations of “命运共同体” in the government work reports(2015-2020)

\begin{tabular}{|c|c|}
\hline Year & Translation \\
\hline 2015 & a community with a common future \\
\hline 2016 & a community of common destiny \\
\hline 2017 & a community of shared future \\
\hline 2018 & a community with a shared future \\
\hline 2019 & a community with a shared future \\
\hline 2020 & a community with a shared future \\
\hline
\end{tabular}

As is demonstrated in the table, before the year 2017 there were mainly two kinds of translation of “命运”, namely "destiny" and "future", while in 2017 and after, "future" is the major way of translation. The expression “命运” reflects Chinese ideology, which is explained as something that is doomed to happen, usually carrying negative implications. Consequently, "destiny" is the direct literal equivalent for “命运”. However, as Lu Jianfei (2018) ${ }^{[11]}$ points out, what President Xi intends to convey by “命运 共同体” is not negative destiny, but a positive longing for the future. Therefore, "future" better suits the context and the ideology of the English readers.

\subsection{The Views of Life}

The white paper records the entire process of Chinese people's fight against COVID-19. The Communist Party of China and the Chinese government accord paramount significance to people's life and health. In the white paper, it is emphasized repeatedly that life is of the greatest importance. Life is described as “至高无上”, which means the most valuable of all, indicating the superlative degree. Nevertheless, when “生命至高无上” is translated into English, it becomes "life is precious", without superlative indications.

Language reflects the differences in ideology. China has long been putting people first, viewing life as the most important of all. Against the backdrop of the pandemic, the Chinese people unite as one, take decisive actions to place lockdowns so as to stop the spreading of the virus. They temporarily lower the speed of economic growth for the better protection of human life and health. In western countries, people uphold individualism. Life is important, yet freedom is also valuable. They try to contain the pandemic while not sacrificing freedom.

Social and cultural realities shape their unique values and ideologies. Influenced by these different ideologies, their views of life also remain divided. As such, translators need to take into account the different ideologies, rendering “生 命至高无上” into "life is precious", to be in keeping with the ideology of the recipients.

\section{PATRONAGE}

As Lefevere (1992) puts it, patronage means something like the powers (persons, institutions) that can further or hinder the reading, writing, and rewriting of literature ( $\mathrm{p}$. 15). The white paper is the official document of the government, representing the stance of the government. Its patronage comes from the Communist Party of China and the Chinese government. Patronage exerts great impact on ideology and poetics, so it is imperative that translators keep the content clear and concise and render the source text in a way that suits the ideology of the English readers.

\section{POETICS}

Lefevere (ibid.) points out that poetics comprises two components: one is an inventory of literary devices, genres, motifs, prototypical characters and situations, and symbols; the other a concept of what the role of literature is in the social system as a whole (p. 26). Poetics formed in different social, economic and political context may vary. Therefore, translators need to be familiar with the poetics of the two languages and make appropriate adjustments where it is necessary.

\subsection{Avoiding Repetition of the Same Meaning}

The Chinese language favors repetition and structural balance and people speaking this language tend to use two or more similar expressions when conveying one concept, 
in order to form balance and achieve emphasis. In contrast, English favors clear and concise words and expressions, usually avoiding repetition of the same meaning.

Example One. Source text: 尽最大努力挽救更多患者生 命是当务之急、重中之重。

Translation: Saving as many lives as possible, by

every possible means, was the number one

priority.

“当务之急” and “重中之重” convey similar meaning in this context. The use of such repetitive expressions is common in Chinese, highlighting the importance and urgency of taking actions to save lives. In light of the poetics of English, the translator does not render the two similar expressions literally, but translates them as "the number one priority", which successfully conveys the meaning and function of the ST.

Example Two. ST: 习近平指出 $[\cdots]$ 要慎终如始、再接再 厉、善作善成。

Translation: He encouraged the people to persevere in their efforts.

As is mentioned in the white paper, President $\mathrm{Xi}$ went to Wuhan City on March 10th to inspect work on epidemic control. He used three similar Chinese phrases to emphasize the significance of staying committed to COVID-19 control, namely, “慎终如始”, “再接再厉”, “善 作善成”. All of the three expressions mean that we need to start well, end well, and remain diligent in our efforts to deal with the pandemic. Yet, when the translator renders them into English, only "persevere" is employed to convey the central meaning. This example illustrates the differences between Chinese poetics and its English counterpart.

Example Three. ST: 中国感谢和铭记国际社会宝贵支持 和帮助

Translation: China Appreciates Support from the International Community

When the COVID-19 broke out, the international community extended great assistance to China. The words “感谢” and “铭记” are used in the white paper to show that Chinese people are grateful for their generous help. Due to the differences in language use, the translator renders “感谢” and “铭记” as "appreciate” alone. As in English, "appreciate" and "remember", if used together, are repetitive to some degree, since to appreciate is on the basis of remembering. As such, the translator uses "appreciate" to convey the meaning.

\subsection{Considering a Change of Diction}

Through calculating the word frequency via online web-based Chinese corpus (http://corpus.zhonghuayuwen.org/CpsTongji.aspx), some high-frequency words have been found out, for example “加强”, “救治” and “抗击” have appeared for 72 times, 66 times and 40 times respectively, while the same Chinese words have been expressed by different words in English. In this part, “加强” is to be the example for analysis. This concept has been translated as various English words, like "call for greater efforts to", "strengthen", "enhance", "improve", "step up", etc. The translator renders the same Chinese words as different English expressions, so as to suit the poetics of the English readers.

\subsection{Changing the Original Form}

Four-character structure is unique in Chinese. It is balanced in structure and concise in expression. Nevertheless, the culture and the way of thinking in the east and the west are quite different. Thus, the translation will be obscure and awkward supposing that the translator seeks word for word rendering in line with the original form. As is often the case, translators seldom retain the four-character form in the target text, but render it sense for sense.

Example Four. ST: 中国 $[. .$.$] 向争分夺秒抢救生命 [\ldots]$ 的 人们深表敬意。

Translation: China [...] extends the greatest respect to those who are struggling to save lives [...].

The Chinese expression “争分夺秒” means that time is limited and people need to seize every minute. In the white paper it is pointed out that medical staff seize every minute to save lives. In the English translation, the four-character form “争分夺秒” is not retained, and the translator changes the ST form to help the recipients understand.

Example Five. ST: 同舟共济、守望相助

Translation: unite and cooperate

Chinese people have upheld friendship and cooperation for long. As globalization proceeds, the world has turned to be a village. The relationship among countries has become closer. As such, the international community should join hands to cope with issues facing them all. As is mentioned in the white paper, the international community should unite and cooperate, and they will win the battle against COVID-19.

The four-character structure “同舟共济、守望相助” is typical in Chinese. The translator renders it as unite and cooperate, changing the original form. “同舟共济” means that the international community should join hands and unite; “守望相助” means that countries should cooperate and help each other. Therefore, the translator renders it as "unite and cooperate", successfully conveying the central meaning.

\subsection{Improving the Awareness of Addition}

In the English version of the white paper, the translator renders “六保” 和 “六稳” as “the six priorities (jobs, daily living needs, food and energy, industrial and supply chains, the interests of market players, and the smooth functioning of grassroots government)" and "stabilize the six fronts -- employment, finance, foreign trade, inbound investment, domestic investment, and market expectations" 
respectively. By adding the specific content, the English readers will find it easier to understand.

\section{CONCLUSION}

Based on the manipulation theory of André Lefevere, this paper discusses the influence of ideology, patronage, and poetics through the analysis of the English version of Fighting COVID-19: China in Action. Publicity translation differs from other types of translation in that it carries the purposes of both translation and publicity. As such, the translator needs to take account of the three factors during the translation process, namely patronage, ideology as well as poetics, and adjust the source text accordingly to help the recipients better understand the text.

\section{REFERENCES}

[1] Hermans, T. (1985). The Manipulation of Literature: Studies in Literary Translation. London and Sydney: Croom Helm.

[2] Bassnett, S., \& Lefevere, A. (1990). Translation, History and Culture. London and New York: Pinter Publishers.

[3] Lefevere, A. (1992). Translation, Rewriting, and the Manipulation of Literary Fame. London and New York: Routledge.

[4] Hu, X.W., \& Zhang, J. (2013).Waixuan fanyi de ming yu shi-Zhangjian jiaoshou fangtanlu [The Name and Nature of Translation for China's Global Communication-An Interview with Professor Zhang Jian of Shanghai International Studies University]. Zhongguo waiyu, 3:100-104.

[5]Zeng, J.P., \& Chen, L. (2018).Waixuan fanyi de tedian ji yuanze [Characteristics and Principles of Translation of International Publicity]. Nanchang hangkong daxue xuebao(shehui kexue ban), 1:51-59.

[6] Hu, W.P. (2007).Yishi xingtai --caozong fanyi de wuxing liliang [Ideology-the Invisible Power in the Process of Translation]. Tongji daxue xuebao, 1:73-77.

[7] Hu, F.Y., \& Jia, W.B. (2010).Waixuan fanyi: yishi xingtai caozong xia de gaixie [China's External-oriented Propaganda Translation:A Rewriting Manipulated by Ideology]. Shanghai fanyi, 1:23-28.

[8] Hu, X.W., \& Wu, A.M. (2013).waixuan fanyi: yishi xingtai he xuanchuan shixue caozong xia de gaixie [International Publicity Translation: A Translation Manipulated by Ideology and Poetics]. Xinan nongye daxue xиebao(shehui kexue ban), 7:94-97.

[9] Wang, H.Y., \& Li, H.H. (2016).cong fanyi caozong lilun kan 2015 zhengfu gongzuo baogao yingyi [A Study on The Government Work Reports(2015) from the Perspective of the Manipulation Theory].xiandai jiaoji, 10:96-97.

[10] Lin, X.X. (2018).cong gaixie lilun kan fanyi dui tisheng guojia huayuquan de zuoyong-yi shijiuda baogao weili[A Study on Translation's Role in Improving a Country's Right of Speech-A Case Study of the Report of the $19^{\text {th }}$ CPC National Congress].haiwai yingyu, 8:130-131.

[11] Lu, J.F. (2018, April 19). mianxiang weilai de "mingyun gongtongti"[Future-Oriented Concept: A Community with a Shared Future ]. shehui kexue bao, P.5. 